may result from straightforward geometrical constraints. This variation may thus be expected in more realistic, numerical simulations of the geodynamo and may provide an important constraint on those models ${ }^{12-14}$.

Received 7 November 2003; accepted 2 March 2004; doi:10.1038/nature02459.

1. Merrill, R. T. \& McFadden, P. L. Geomagnetic polarity transitions. Rev. Geophys. 37, 201-226 (1999).

2. Singer, B. S. \& Pringle, M. S. Age and duration of the Matuyama-Brunhes geomagnetic polarity reversal from ${ }^{40} \mathrm{Ar} /{ }^{39} \mathrm{Ar}$ incremental heating analyses of lavas. Earth Planet. Sci. Lett. 139, 47-61 (1996).

3. McElhinny, M. W. \& Lock, J. IAGA paleomagnetic databases with access. Surv. Geophys. 17, 575-591 (1996).

4. Channell, J. E. T. \& Lehman, B. The last two geomagnetic polarity reversals recorded in highdeposition-rate sediment drifts. Nature 389, 712-715 (1997)

5. Yamazaki, T. \& Oda, H. Orbital influence on Earth's magnetic field; 100,000 -year periodicity in inclination. Science 295, 2435-2438 (2002).

6. Oda, H., Shibuya, H. \& Hsu, V. Palaeomagnetic records of the Brunhes/Matuyama polarity transition from ODP Leg 124 (Celebes and Sulu seas). Geophys. J. Int. 142, 319-338 (2000).

7. Fisher, R. A. Dispersion on a sphere. Proc. R. Astron. Soc. A 217, 295-305 (1953).

8. Channell, J. E. T., Hodell, D. A. \& Lehman, B. Relative geomagnetic paleointensity and $\delta^{18} \mathrm{O}$ at ODP Site 983 (Gardar Drift, North Atlantic) since 350 ka. Earth Planet. Sci. Lett. 153, 103-118 (1997).

9. Cande, S. C. \& Kent, D. V. Revised calibration of the geomagnetic polarity time scale for the Late Cretacous and Cenozoic. J. Geophys. Res. 100, 6093-6095 (1995).

10. Holt, J. W. \& Kirschvink, J. L. The upper Olduvai geomagnetic field reversal from Death Valley, California; a fold test of transitional directions. Earth Planet. Sci. Lett. 133, 475-491 (1995).

11. Clement, B. M. \& Kent, D. V. Latitudinal dependency of geomagnetic polarity transition durations. Nature 310, 488-491 (1984)

12. Dormy, E., Valet, J.-P. \& Courtillot, V. Numerical models of the geodynamo and observational constraints. Geochem. Geophys. Geosyst. 1, doi:2000GC000062 (2000).

13. McMillan, D. G., Constable, C. G., Parker, R. L. \& Glatzmaier, G. A. A statistical analysis of magnetic fields from some geodynamo simulations. Geochem. Geophys. Geosyst.[online] 28, doi:2000GC000130 (2001).

14. Coe, R. S., Hongre, L. \& Glatzmaier, G. A. An examination of simulated geomagnetic reversals from a palaeomagnetic perspective. Phil. Trans. R. Soc. 358, 1141-1170 (2000).

15. Clement, B. M. \& Kent, D. V. A southern hemisphere record of the Matuyama-Brunhes polarity reversal. Geophys. Res. Lett. 18, 81-84 (1991).

16. Theyer, F., Herrero-Bervera, E., Hsu, V. \& Hammond, S. R. The zonal harmonic model of polarity transitions; a test using successive reversals. J. Geophys. Res. B 90, 1963-1982 (1985).

17. Valet, J.-P., Tauxe, L. \& Clement, B. Equatorial and mid-latitude records of the last geomagnetic reversal from the Atlantic Ocean. Earth Planet. Sci. Lett. 94, 371-384 (1989).

18. Clement, B. M., Kent, D. V. \& Opdyke, N. D. Brunhes-Matuyama polarity transition in three deep-sea sediment cores. Phil. Trans. R. Soc. Lond. 306, 113-119 (1982).

19. Cisowski, S. M. et al. Detailed record of the Brunhes/Matuyama polarity reversal in high sedimentation rate marine sediments from the Isu-Bonin Arc. Proc. ODP Sci. Res. 126, 341-352 (1992).

20. Zhu, R., Laj, C. \& Mazuad, A. The Matuyama-Brunhes and upper Jaramillo transitions recorded in a loess section at Weinan, north-central China. Earth Planet. Sci. Lett. 125, 143-158 (1994).

21. Okada, M. \& Niitsuma, N. Detailed paleomagnetic records during the Brunhes-Matuyama geomagnetic reversal, and a direct determination of depth lag for magnetization in marine sediments. Phys. Earth Planet. Inter. 56, 133-150 (1989).

22. Valet, J.-P., Tauxe, L. \& Clark, C. R. The Brunhes-Matuyama transition recorded from Lake Tecopa sediments (California). Earth Planet. Sci. Lett. 87, 463-472 (1988).

23. Clement, B. M., Kent, D. V. Geomagnetic polarity transition records from five hydraulic piston core sites in the North Atlantic. in Init. Rep. Deep Sea Drilling Project (ed. Ruddiman, W. F. et al.) 94, 831-852 (US Government Printing Office, Washington, 1987).

24. Athanossopolous, J. A Matuyama-Brunhes Polarity Reversal Record; Comparison Between Thermal and Alternating Field Demagnetization of Ocean Sediments from the North Pacific Transect. PhD thesis, Univ. California, Santa Barbara, 225 (1993).

25. Herrero-Bervera, E. \& Theyer, F. Non-axisymmetric behaviour of Olduvai and Jaramillo polarity transitions recorded in north-central Pacific deep-sea sediments. Nature 322, 159-162 (1986).

26. Clement, B. M. \& Kent, D. V. A detailed record of the lower Jaramillo polarity transition from a southern hemisphere, deep-sea sediment core. J. Geophys. Res. 89, 1049-1058 (1984).

27. Gee, J. S. et al. Lower Jaramillo polarity transition records from the equatorial Atlantic and Indian oceans. Proc. ODP Sci. Res. 121, 377-391 (1991).

28. Clement, B. M. \& Kent, D. V. A comparison of two sequential geomagnetic polarity transitions (upper Olduvai and lower Jaramillo) from the Southern Hemisphere. Phys. Earth Planet. Inter. 39, 301-313 (1985).

29. Herrero-Bervera, E. \& Khan, M. A. Olduvai termination; detailed palaeomagnetic analysis of a north central Pacific core. Geophys. J. Int. 108, 535-545 (1992).

Acknowledgements R. Coe, D. V. Kent, J. Dauphin \& B. Midson provided comments that improved the manuscript. J. E. T. Channell and T. Yamazaki provided their data for this work.

Competing interests statement The authors declare that they have no competing financial interests.

Correspondence and requests for materials should be addressed to B.M.C. (clementb@fiu.edu).

\section{Effectiveness of the global protected area network in representing species diversity}

\author{
Ana S. L. Rodrigues ${ }^{1}$, Sandy J. Andelman ${ }^{3}$, Mohamed I. Bakarr ${ }^{4}$, \\ Luigi Boitani ${ }^{5}$, Thomas M. Brooks ${ }^{1}$, Richard M. Cowling ${ }^{6}$, \\ Lincoln D. C. Fishpool ${ }^{7}$, Gustavo A. B. da Fonseca ${ }^{1,8}$, Kevin J. Gaston', \\ Michael Hoffmann ${ }^{1}$, Janice S. Long ${ }^{2}$, Pablo A. Marquet ${ }^{10}$, \\ John D. Pilgrim ${ }^{1}$, Robert L. Pressey ${ }^{11}$, Jan Schipper ${ }^{12}$, Wes Sechrest ${ }^{2}$, \\ Simon N. Stuart ${ }^{2}$, Les G. Underhill ${ }^{13}$, Robert W. Waller ${ }^{1}$, \\ Matthew E. J. Watts ${ }^{14}$ \& Xie Yan ${ }^{15}$
}

${ }^{1}$ Center for Applied Biodiversity Science, and ${ }^{2} I U C N-S S C / C I-C A B S$ Biodiversity Assessment Unit, Conservation International, Washington, DC 20036, USA

${ }^{3}$ National Center for Ecological Analysis and Synthesis, University of California, Santa Barbara, California 93101, USA

${ }^{4}$ World Agroforestry Centre (ICRAF), Gigiri Nairobi, Kenya

${ }^{5}$ Dipartimento di Biologia Animale e dell'Uomo, Università di Roma

'La Sapienza', 00185 Rome, Italy

${ }^{6}$ Terrestrial Ecology Research Unit, Department of Botany, University of Port Elizabeth, Port Elizabeth 6000, South Africa

${ }^{7}$ BirdLife International, Cambridge CB3 ONA, UK

${ }^{8}$ Departmento de Zoologia, Universidade Federal de Minas Gerais, Belo Horizonte 31270, Brazil

${ }^{9}$ Biodiversity and Macroecology Group, Department of Animal and Plant Sciences, University of Sheffield, Sheffield S10 2TN, UK

${ }^{10}$ Center for Advanced Studies in Ecology and Biodiversity (CASEB) and

Departamento de Ecología, Facultad de Ciencias Biológicas, Pontificia

Universidad Católica de Chile, Casilla 114-D, Santiago, Chile

${ }^{11}$ New South Wales Department of Environment and Conservation, Armidale, New South Wales 2350, Australia

${ }^{12}$ Department of Fish and Wildlife Resources, University of Idaho, Moscow, Idaho 83844, USA

${ }^{13}$ Avian Demography Unit, Department of Statistical Sciences, University of Cape Town, Rondebosch 7701, South Africa

${ }^{14} 194$ W Hill Street, Walcha, New South Wales 2354, Australia

${ }^{15}$ Institute of Zoology, Chinese Academy of Sciences, Beijing 100080, China

The Fifth World Parks Congress in Durban, South Africa, announced in September 2003 that the global network of protected areas now covers $11.5 \%$ of the planet's land surface ${ }^{1}$. This surpasses the $10 \%$ target proposed a decade earlier, at the Caracas Congress $^{2}$, for 9 out of 14 major terrestrial biomes ${ }^{1}$. Such uniform targets based on percentage of area have become deeply embedded into national and international conservation planning $^{3}$. Although politically expedient, the scientific basis and conservation value of these targets have been questioned ${ }^{4,5}$. In practice, however, little is known of how to set appropriate targets, or of the extent to which the current global protected area network fulfils its goal of protecting biodiversity. Here, we combine five global data sets on the distribution of species and protected areas to provide the first global gap analysis assessing the effectiveness of protected areas in representing species diversity. We show that the global network is far from complete, and demonstrate the inadequacy of uniform-that is, 'one size fits all'-conservation targets.

Systematic approaches to conservation planning have been developed over the last two decades to guide the efficient allocation of the scarce resources available for protecting biodiversity ${ }^{6}$. Gap analysis is a planning approach based on assessment of the comprehensiveness of existing protected area networks and identification of gaps in coverage $^{7,8}$. It has also been developed into a formal method now applied by the US Geological Survey National Gap Analysis Program $^{9}$ and others. Numerous gap analyses at regional scales reveal that coverage of biodiversity by existing networks of protected areas is inadequate $e^{10,11}$. Furthermore, many such networks are 
letters to nature

\begin{tabular}{|c|c|c|c|c|c|c|}
\hline \multirow[t]{2}{*}{ Taxon } & \multirow{2}{*}{$\begin{array}{l}\text { Median range size } \\
\left(\mathrm{km}^{2}\right)\end{array}$} & \multicolumn{5}{|c|}{ Numbers of gap species } \\
\hline & & $\begin{array}{l}\text { Current network } \\
\text { (all PAs) }\end{array}$ & $\begin{array}{c}\text { Current network } \\
\text { (PAs }>1,000 \text { ha and IUCN I-IV) }\end{array}$ & $\begin{array}{c}\text { Model I } \\
\text { (equal area sites) }\end{array}$ & $\begin{array}{c}\text { Model II } \\
\text { (variable area sites) }\end{array}$ & $\begin{array}{c}\text { Model III } \\
\text { (tropical bias) }\end{array}$ \\
\hline \multicolumn{7}{|l|}{ All species } \\
\hline Mammals $(n=4,735)$ & 247,341 & 258 (5.5\%) & 644 (13.5\%) & 297.7 (6.3\%) & $342.3(7.2 \%)$ & $226.6(4.8 \%)$ \\
\hline Turtles $(n=273)$ & 309,172 & $21(7.7 \%)$ & $48(17.6 \%)$ & $24.6(9.0 \%)$ & $26.5(9.7 \%)$ & $23.8(8.7 \%)$ \\
\hline Amphibians $(n=5,454)$ & 7,944 & $913(16.7 \%)$ & $1,718(31.5 \%)$ & $1,230.2(22.6 \%)$ & $1,507.8(27.7 \%)$ & $804.2(14.7 \%)$ \\
\hline \multicolumn{7}{|l|}{ Threatened species } \\
\hline Mammals $(n=1,063)$ & 22,902 & $149(14.0 \%)$ & 314 (29.6\%) & 191.8 (18.0\%) & $218.2(20.5 \%)$ & $151.6(14.3 \%)$ \\
\hline Birds $(n=1,171)$ & 4,015 & 232 (19.8\%) & 437 (37.3\%) & 349.7 (29.9\%) & 409.6 (35.0\%) & $275.4(23.5 \%)$ \\
\hline Turtles $(n=119)$ & 167,611 & $12(10.1 \%)$ & 32 (26.9\%) & $15.9(13.3 \%)$ & $17.3(14.6 \%)$ & $15.5(13.1 \%)$ \\
\hline Amphibians $(n=1,543)$ & 896 & $411(26.6 \%)$ & 767 (49.7\%) & $604.5(39.2 \%)$ & $740.0(48.0 \%)$ & $423.3(27.4 \%)$ \\
\hline $\begin{array}{l}\text { All species analysed } \\
\qquad(n=11,633)\end{array}$ & 38,229 & $1,424(12.2 \%)$ & 2,847 (24.5\%) & 1,902.3 (16.4\%) & 2,286.2 (19.7\%) & 1,330.3 (11.4\%) \\
\hline
\end{tabular}

The total numbers of species and their respective median range size are given for comparative purposes. Values in parentheses are the percentage of all species/threatened species analysed within a given taxon. PAs, protected areas.

skewed towards particular ecosystems, often those that are less economically valuable, leaving others inadequately protected ${ }^{12}$. At the global scale, however, the degree to which biodiversity is represented within the existing network of protected areas is unknown.

In this analysis, we considered a species to be a 'covered species' if any protected area overlapped any extent of its mapped distribution, and otherwise to be a 'gap species'. Overall, 1,424 gap species ( $12 \%$ of all species analysed) were identified (Table 1$)$. Protected areas may not retain all of their species if they are too small to maintain viable populations ${ }^{13}$ or if they are used extractively ${ }^{14}$. Of the covered species, 1,423 were not represented in any protected area larger than 1,000 ha and in stricter conservation classifications (The World Conservation Union (IUCN) categories $\mathrm{I}_{-} \mathrm{IV}^{15}$ ). Threatened and restricted-range species are those of most conservation concern ${ }^{16-18}$. Sets of species with smaller median range sizes tend to have a higher proportion of gap species (Table 1). Hence, amphibians are the least represented taxon and, within any given taxon, threatened species (which tend to have smaller ranges) have proportionally higher numbers of gap species than do all species considered together. Overall, $20 \%$ of all threatened species analysed were identified as gap species.

The number of covered species is an overestimate, mainly because of two unrealistic assumptions. First, all protected areas are considered to be adequate for protecting every species, whereas in reality even those classified in IUCN categories I-IV vary substantially in the degree of effectiveness and enforcement ${ }^{19}$. Second, it assumes that species can be protected equally effectively in any part of their range, regardless of habitat suitability, and by the protection of any fraction of that range, regardless of viability constraints. In practice, simple presence within a protected area is insufficient to ensure the long-term persistence of many species, particularly those with demanding habitat or area requirements ${ }^{13}$, and does not consider threats such as global climate change ${ }^{20}$.

As species are only considered to be gap species if they are not touched by any protected area, concentrations of gap species in a

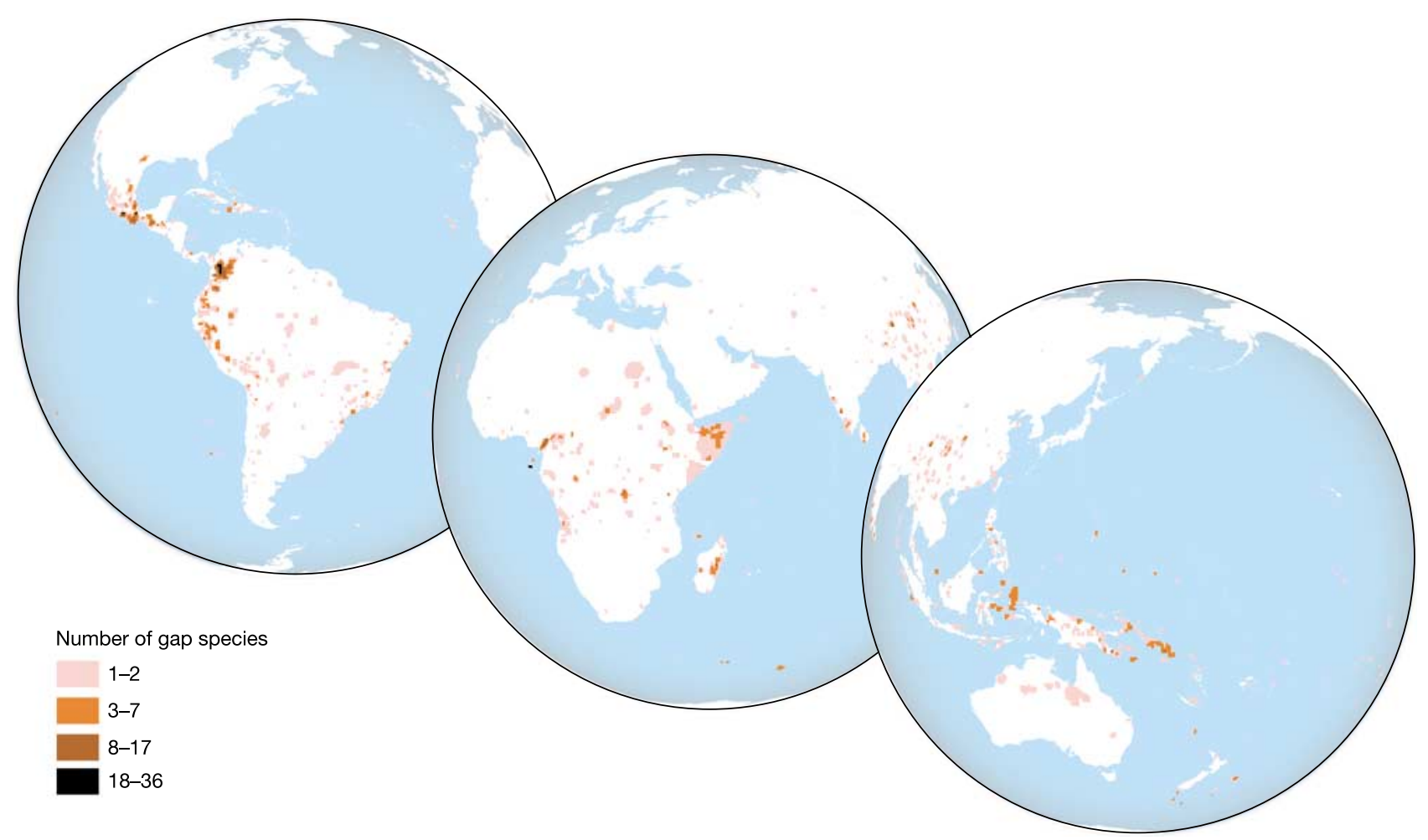

Figure 1 Density map of gap species per half-degree cell, created by overlaying the ranges of all species not covered by any protected area. 

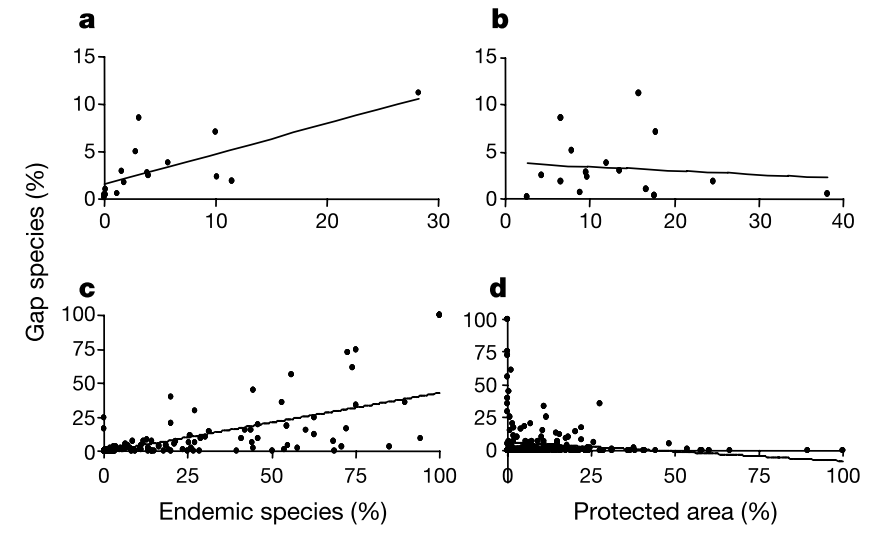

Figure 2 Percentage of gap species in relation to endemism levels and percentage of area protected across biomes and countries. a-d, Relationships between: percentage of species in each biome that are endemic and percentage that are gap species (a) $(n=16$, $r=0.72, P<0.005)$; percentage of each biome's protected area and percentage of gap species $(\mathbf{b})(P>0.5)$; percentage of species in each country that are endemic and percentage that are gap species $(\mathbf{c})(n=247, r=0.69, P<0.001)$; percentage of each country's protected area and percentage of gap species $(\mathbf{d})(n=247, r=0.15$, $P<0.05)$.

given region may be explained by sparse protected area coverage and/or by a concentration of narrowly distributed species. The global distribution of gap species (Fig. 1) is influenced more strongly by the latter. Indeed, within a given biome ${ }^{21}$, the percentage of species that are gaps is highly significantly correlated with the level of endemism, independent of the percentage of area protected (Fig. 2a, b). Across countries, the percentage of gap species decreases with percentage of area protected, but is more strongly correlated with levels of national endemism (Fig. 2c, d). Consequently, although in some regions the absence of protected areas allows for relatively widespread gap species (notably in Somalia), the map of gap species mainly reflects the presence of narrowly distributed species (Fig. 1). The regions highlighted include many widely recognized centres of endemism ${ }^{16,22}$, such as Yunnan province and the mountains surrounding the Sichuan basin in southern China, the Western Ghats of India, Sri Lanka, the islands of Southeast Asia and Melanesia, the Pacific islands, Madagascar, the Cameroon highlands, Mesoamerica, the tropical Andes, the Caribbean, and the Atlantic Forest of South America. Most of these are montane or insular regions in the tropics.

These results have implications for global conservation planning strategies, as they clearly demonstrate that the percentage of area already protected in a given country or biome is a very poor indicator of additional conservation needs. Contrary to frequent recommendations $s^{1,23}$, current protection levels should not be used as a significant criterion to guide priorities for allocation of future conservation investments. Indeed, the regions with greatest need for expansion of the global protected area network are not necessarily those with a lower percentage of their area protected; rather, they typically are those with higher levels of endemism ${ }^{24}$. Conversely, uniform targets based on percentage of area protected (except for $100 \%$ ) cannot be used as a ceiling to distinguish between regions sufficiently protected and those that need additional protection ${ }^{4-5}$.

Global conservation strategies based on the recommendation that $10 \%$ (or other similar targets) of each country or biome be protected will not be effective because they are blind to the fact that biodiversity is not evenly distributed across the planet ${ }^{25}$; by the same token, neither should protected areas be. Indeed, a network with the same total area as the existing one but evenly distributed across the world would perform less adequately than the current network in representing species of mammals, amphibians, turtles and threatened birds (Table 1). The better performance of the current network indicates uneven distribution of protected areas relative to biodiversity pattern. Indeed, the current network is significantly (albeit not overwhelmingly) biased towards sites with higher richness of all species, restricted-range species and threatened species. This may be the legacy of decisions to locate some protected areas in better sites, and/or be symptomatic of higher levels of biodiversity loss outside protected areas ${ }^{19}$. Nonetheless, the current global network could still perform better in terms of species coverage. For example, a network biased towards the tropics (to match their higher level of endemism) would have fewer gap species than the current network, and far fewer gap species than a random unbiased network (Table 1).

Our results demonstrate that if the conservation goal is species representation, then the expansion of the global network of protected areas must account for biodiversity patterns, rather than rely on general percentage-based targets that are formed largely by political and feasibility considerations ${ }^{4-5}$. Given the increasing threats to biodiversity, such expansion should be made strategically by focusing on those regions that would contribute most to the global system and prioritizing, within those, the regions where the urgency for conservation action is greatest ${ }^{22}$. Conservation strategies must also address the complexity of natural ecosystems, including genetic and phylogenetic diversity, and ecological and evolutionary processes ${ }^{26}$.

The existing protected area network provides an invaluable service in shielding habitat from destructive use and hence in reducing biodiversity loss ${ }^{19}$. However, our global gap analysis clearly demonstrates that the global protected area network is still far from complete, even for terrestrial vertebrates, the best known and most popular of all species groups ${ }^{27}$. Of the species considered, at least $12 \%$ are not represented in any protected area, despite the extremely strict assumptions applied for identifying gap species. It is likely that other taxa with high levels of endemism, such as plants and insects, are even less well represented, given the tendency for sets of species with smaller range sizes to have higher proportions of gap species.

Protected areas are not the only tactic available to conservation planners, but they are highly cost effective in protecting biodiversity $^{28}$. Advances in data availability and in the science of conservation planning enable us to act strategically in the face of increasing human pressure. Clearly, the task ahead is as urgent as it is challenging, as much biodiversity remains to be protected.

\section{Methods}

Data

Data on the global distribution of protected areas were obtained from the 2003 World Database on Protected Areas ${ }^{29}$. Distribution maps were obtained for 11,633 species of terrestrial vertebrates: 4,735 terrestrial mammals, compiled by the IUCN Global Mammal Assessment; 1,171 globally threatened birds ${ }^{17} ; 273$ freshwater turtles and tortoises ${ }^{30}$; and 5,454 amphibians, compiled by the IUCN Global Amphibian Assessment. These species data also include assessments of conservation status, with 1,063 mammals, 1,171 birds, 119 turtles and 1,543 amphibians having been listed as globally threatened by the IUCN Red List ${ }^{17-18}$. See Supplementary Information for more details.

\section{Randomly distributed networks}

Two null models were created to simulate a network of protected areas with similar characteristics to the existing one, but evenly spread around the world: Model I (equal area sites), 69,794 circles, of the same size as the mean area of a protected site, and 11,119 points were randomly spread around the world's land surface (excluding Antarctica); Model II (variable area sites), 69,794 circles, with the same distribution of sizes as the current protected area network, and 11,119 points were randomly spread around the world's land surface (excluding Antarctica).

Of all species that are restricted to either the tropical or the non-tropical regions (that is, excluding species that span both), $75.8 \%$ are found in the tropics; however, only $45.8 \%$ of the global protected area network is in the tropics. Therefore, we considered a third model in which the percentage of the global protected area in the tropics was increased to match its level of endemism: Model III (tropical bias), 69,794 circles, of the same size as the mean area of a protected site, and 11,119 points were distributed such that $75.8 \%$ of each occurred in the topics, having random distributions within tropical and non-tropical areas. 
Sixty replicates were obtained for each of these randomly distributed networks. These were then overlaid with species distributional data to analyse the number of gap species in each case. See Supplementary Information for the confidence intervals for each of the models.

\section{Richness of protected and unprotected cells}

The richness of each quarter-degree cell touching land (outside Antarctica) was calculated for all species, restricted-range species ${ }^{16}$ (occupying $\leq 50,000 \mathrm{~km}^{2}$ ) and threatened species. Cells touching protected areas were considered 'protected'. Protected cells are significantly $(P<0.001)$ biased towards higher richness of all, restricted-range and threatened species. See Supplementary Information for a comparison of frequency distributions.

Received 21 December 2003; accepted 11 February 2004; doi:10.1038/nature02422.

1. Chape, S., Fish, L., Fox, P. \& Spalding, M. United Nations List of Protected Areas (IUCN/UNEP, Gland, Switzerland/Cambridge, UK, 2003).

2. The World Conservation Union. Parks For Life: Report of the IVth World Congress on National Parks and Protected Areas (IUCN, Gland, Switzerland, 1993).

. Kamden-Toham, A. et al. Forest conservation in the Congo Basin. Science 299, 346 (2003).

4. Soulé, M. E. \& Sanjayan, M. A. Conservation targets: do they help? Science 279, 2060-2061 (1998).

5. Pressey, R. L., Cowling, R. M. \& Rouget, M. Formulating conservation targets for biodiversity pattern and process in the Cape Floristic Region, South Africa. Biol. Conserv. 112, 99-127 (2003)

6. Margules, C. R. \& Pressey, R. L. Systematic conservation planning. Nature 405, 243-253 (2000).

7. Scott, J. M. et al. Gap analysis-a geographic approach to protection of biological diversity. Wildl. Monogr. 123, 1-41 (1993)

8. Lacher, T. E. Jr in GIS Methodologies for Developing Conservation Strategies (eds Savitsky, B. G. \& Lacher, T. E. Jr) 199-209 (Columbia Univ. Press, New York, 1998).

9. Jennings, M. D. Gap analysis: Concepts, methods, and recent results. Landscape Ecol. 15, 5-20 (2000).

10. Scott, J. M. et al. Nature reserves: Do they capture the full range of America's biological diversity? Ecol. Appl. 11, 999-1007 (2001)

11. Andelman, S. J. \& Willig, M. R. Present patterns and future prospects for biodiversity in the Western Hemisphere. Ecol. Lett. 6, 818-824 (2003).

12. Pressey, R. L. Ad hoc reservations-Forward or backward steps in developing representative reserve systems? Conserv. Biol. 8, 662-668 (1994).

13. Newmark, W. D. Insularization of Tanzanian parks and the local extinction of large mammals. Conserv. Biol. 10, 1549-1556 (1996).

14. Peres, C. A. \& Lake, I. R. Extent of nontimber resource extraction in tropical forests: accessibility to game vertebrates by hunters in the Amazon basin. Conserv. Biol. 17, 521-535 (2003).

15. The World Conservation Union, Guidelines for Protected Area Management Categories (IUCN CNPPA/WCMC, Gland, Switzerland/Cambridge, UK, 1994).

16. Stattersfield, A. J., Crosby, M. J., Long, A. J. \& Wege, D. C. Endemic Bird Areas of the World_Priorities for Biodiversity Conservation (BirdLife International, Cambridge, UK, 1998).

17. BirdLife International. Threatened Birds of the World (Lynx Edicions/BirdLife International, Barcelona/Cambridge, UK, 2000).

18. The World Conservation Union. IUCN Red List of Threatened Species [online] 〈http:// www.redlist.org $\rangle$ (2003)

19. Bruner, A. G., Gullison, R. E., Rice, R. E. \& Fonseca, G. A. B. Effectiveness of parks in protecting tropical biodiversity. Science 291, 125-128 (2001).

20. Thomas, C. D. et al. Extinction risk from climate change. Nature 427, 145-148 (2004)

21. Olson, D. M. et al. Terrestrial ecoregions of the world: A new map of life on earth. Bioscience 51, 933-938 (2001)

22. Myers, N., Mittermeier, R. A., Mittermeier, C. G., Fonseca, G. A. B. \& Kent, J. Biodiversity hotspots for conservation priorities. Nature 403, 853-858 (2000).

23. Green, M. J. B. \& Paine, J. State of the World's Protected Areas at the End of the Twentieth Century (WCMC, Cambridge, UK, 1997).

24. Rodrigues, A. S. L. \& Gaston, K. J. How large do reserve networks need to be? Ecol. Lett. 4, 602-609 (2001).

25. Gaston, K. J. Global patterns in biodiversity. Nature 405, 220-227 (2000).

26. Cowling, R. M. \& Pressey, R. L. Rapid plant diversification: planning for an evolutionary future. Proc Natl Acad. Sci. USA 98, 5452-5457 (2001).

27. Gaston, K. J. \& May, R. M. Taxonomy of taxonomists. Nature 356, 281-282 (1992).

28. Balmford, A. et al. Economic reasons for conserving wild nature. Science 297, 950-953 (2002).

29. World Database on Protected Areas. World Database on Protected Areas (IUCN-WCPA/UNEPWCMC, Washington DC, 2003).

30. Iverson, J. B., Kiester, A. R., Hughes, L. E. \& Kimerling, A. J. The EMYSystem World Turtle Database 2003 [online] 〈http://emys.geo.orst.edu〉 (2003).

Supplementary Information accompanies the paper on www.nature.com/nature

Acknowledgements We thank the Moore Family Foundation, the Howard Gilman Foundation and the National Center for Ecological Analysis and Synthesis of the University of California Santa Barbara for support. The analysis was possible thanks to the combined effort of the thousands of individuals and hundreds of institutions who collected and compiled the data, or provided financial support for such efforts. We are grateful to the numerous individuals who contributed to this analysis, especially to K. Buhlmann, S. Butchart, N. Cox, P. P. van Dijk, J. Iverson, R. Kiester T. Lacher and B. Young. H. Possingham made valuable comments on the manuscript. Figure 1 was generated by J. Seeber.

Competing interests statement The authors declare that they have no competing financial interests.

Correspondence and requests for materials should be addressed to A.S.L.R.

(a.rodrigues@conservation.org).

\section{Spatial structure often inhibits the evolution of cooperation in the snowdrift game}

\author{
Christoph Hauert \& Michael Doebeli
}

Departments of Zoology and Mathematics, University of British Columbia, 6270 University Boulevard, Vancouver, British Columbia V6T 1Z4, Canada

Understanding the emergence of cooperation is a fundamental problem in evolutionary biology ${ }^{1}$. Evolutionary game theory ${ }^{2,3}$ has become a powerful framework with which to investigate this problem. Two simple games have attracted most attention in theoretical and experimental studies: the Prisoner's Dilemma ${ }^{4}$ and the snowdrift game (also known as the hawk-dove or chicken game $)^{5}$. In the Prisoner's Dilemma, the non-cooperative state is evolutionarily stable, which has inspired numerous investigations of suitable extensions that enable cooperative behaviour to persist. In particular, on the basis of spatial extensions of the Prisoner's Dilemma, it is widely accepted that spatial structure promotes the evolution of cooperation ${ }^{6-8}$. Here we show that no such general predictions can be made for the effects of spatial structure in the snowdrift game. In unstructured snowdrift games, intermediate levels of cooperation persist. Unexpectedly, spatial structure reduces the proportion of cooperators for a wide range of parameters. In particular, spatial structure eliminates cooperation if the cost-to-benefit ratio of cooperation is high. Our results caution against the common belief that spatial structure is necessarily beneficial for cooperative behaviour.

The Prisoner's Dilemma illustrates that cooperating individuals are prone to exploitation, and that natural selection should favour cheaters. In this game, two players simultaneously decide whether to cooperate or defect. Cooperation results in a benefit $b$ to the recipient but incurs a cost $c$ to the donor $(b>c>0)$. Mutual cooperation thus pays a net benefit of $R=b-c$, whereas mutual defection results in payoff $P=0$ for both players. With unilateral cooperation, defection yields the highest payoff, $T=b$, at the expense of the cooperator bearing the cost $S=-c$. It follows that it is best to defect regardless of the co-player's decision. Thus, defection is the evolutionarily stable strategy, even though all individuals would be better off if they all cooperated. This outcome is a simple consequence of the ranking of the four payoff values: $T>R>P>S$. Despite this seemingly convincing argument, many natural species show altruism, with individuals bearing costs to the benefit of others: vampire bats share blood ${ }^{9}$, alarm calls warn from predators ${ }^{10}$, monkeys groom each other ${ }^{11}$, and fish inspect predators preferably in pairs ${ }^{12}$.

In field and experimental studies it is often difficult to assess the fitness payoffs for different behavioural patterns, and even the proper ranking of the payoffs is challenging ${ }^{13,14}$. This has led to a considerable gap between theory and experimental evidence, and to an increasing discomfort with the Prisoner's Dilemma as the only model to discuss cooperative behaviour ${ }^{15,16}$. The snowdrift game is a viable and biologically interesting alternative. It differs from the Prisoner's Dilemma in that the payoffs $P$ and $S$ have a reverse order: $T>R>S>P$. This changes the situation fundamentally and leads to persistence of cooperation.

To illustrate the snowdrift game, imagine two drivers that are caught in a blizzard and trapped on either side of a snowdrift. They can either get out and start shovelling (cooperate) or remain in the car (defect). If both cooperate, they have the benefit $b$ of getting home while sharing the labour $c$. Thus, $R=b-c / 2$. If both defect, they do not get anywhere and $P=0$. If only one shovels, however, they both get home but the defector avoids the labour cost and gets 